\title{
REFERENCES
}

Berry, W. T. C. (1954). Br. F, Nutr. 8, 165.

Berry, W. T. C. (1966). Int. Congr. Nutr. vir. Hamburg. (In the Press.)

Berry, W. T. C. \& Hollingsworth, D. F. (r963). Proc, Nutr. Snc. 22, 48.

Bransby, E. R., Berry, W. T. C. \& Taylor, D. M. (1964). Br. med. F. i, 166r.

British Medical Association (1950). Report of the Committee on Nutrition, p.23. London: British Medical Association.

British Paediatric Association (1964). Br. med. F. i, 1659.

Central and Scottish Health Scrvices Councils (1957). Report of the foint Sub-Committee on Welfare Foods, London: H.M. Stationery Office.

Ministry of Health (1967). Report on Pilot Survey of Nutrition of Pre-school Children. London: H.M. Stationery Office.

Murray, M. M., Ryle, J. A., Simpson, B. W. \& Wilson, D. C. (1948). Med. Res. Coun. Memo. no. 18. Scott, J. A. (1961). Repart on the Heights and Weights (and other Measurements) of School Pupils in the County of London in 1959 . London County Council Report no. 4086.

Taylor, G. F. \& Chuttani, P. N. (1949). Br. med. \%. ii, 784 .

World Health Organization: Study Group on Endemic Goitre (1953). Bull. Wld Hlth Org. no. 9, p. 300.

\section{Some aspects of the implementation of food policy}

By H. R. Barnell, T. J. Coomes and Dorothy F. Hollingsworth, Ministry of Agriculture, Fisheries and Food, London, $S W_{\mathrm{I}}$

\section{Introduction}

The subject is limited to some aspects of the implementation of food policy because it is too wide to be dealt with in its entirety and because the framework of supply and distribution of our food imposes limitations.

Half our food is produced at home and half imported. The imported supplies enter on a free market modified in some instances by international agreements, while home-produced food is encouraged by a price support system for farmers which enables it to compete with the usually cheaper imports. Excepting liquid milk, there is no form of price control to the consumer.

For the population as a whole policy is concerned with protection of the public from contamination of food with harmful micro-organisms and filth, with possibly dangerous additives either deliberate, e.g. colours, or adventitious, e.g., pesticide and other residues, and from misleading claims. The policy objective is clean, safe food with full retention, so far as possible, of nutritive value and the encouragement of research and development towards these ends and towards increasingly efficient methods of processing, storage and distribution.

Within the framework of our food position it is possible to make certain limited arrangements for helping particularly vulnerable groups of the population which will be described.

\section{Measures affecting the whole population}

Responsibilities for regulations as to the composition of food are shared by the Ministers of Agriculture, Fisheries and Food and of Health, using the Statutory powers conferred on them by Section 4 of the Food and Drugs Act, 1955. This 
Section of the Act also requires Ministers to restrict as far as it is practicable the use of substances of no nutritional value as foods, or as ingredients of foods. All foods sold for consumption in the United Kingdom are subject to the requirements authorized by this section with the single exception of milk, for which separate controls under another part of the Act are imposed.

To advise them on their responsibilities in respect of regulations authorized in this manner, Ministers have set up two bodies of independent experts on food and related topics. These experts constitute on the one hand the Food Standards Committee, whose responsibilities embrace both compositional standards and regulations relating to description, labelling and advertisement of food controlled under Sections 6 and 7 of the Act; on the other hand, the Food Additives and Contaminants Committee advises on the desirability or otherwise of permissive use of food adjuncts or ingredients not normally considered of nutritional value but currently necessary with the increasing need to apply science and technology to production, preservation, storage and marketing.

Both the Food Standards Committee and the Food Additives and Contaminants Committee may refer matters of both toxicological hazard and safety-in-use of foods and food adjuncts to the Pharmacology Sub-Committee of the Ministry of Health's Committee on Medical Aspects of Food Policy.

Examples of the regulations enacted following reports by the Food Standards Committee are the Bread and Flour Regulations, I963 (Great Britain: Parliament, ${ }_{1963}$ ), in which compositional requirements in respect of flour are prescribed, and the Food Standards (Butter and Margarine) Regulations, I955 (Great Britain: Parliament, I955) in conjunction with the Food Standards (Margarine) Order, I954 (Great Britain: Parliament, I954a), in which both the composition of margarine and its supplementary additions of both vitamins $A$ and $D$ are prescribed.

The Food Standards Committee has given much attention to labelling, which has been the subject of two recent reviews (Ministry of Agriculture, Fisheries and Food: Food Standards Committee, I 964, 1966) covering firstly labelling principles which should be applied to all foods and secondly claims and misleading descriptions on labels and in advertisements. Section 6 of the Food and Drugs Act, I955 provides general protection against false or misleading words and descriptions, but the Committee consider specific control to deal with particular problems and abuses is merited.

The functions of the Food Additives and Contaminants Committee are similarly consumer-protective, although health hazard is the primary consideration guiding the deliberations of its members. The control method of choice in respect of any food additive is the 'permitted list', by means of which only those compounds, on which evidence both of technological need and safety-in-use has been accumulated and scrutinised, are permitted for use in food, usually at specified levels of addition for individual foods. Recent examples of the work of this committee are available in the Colouring Matters in Food Regulations, 1966 (Great Britain: Parliament, 1966b) and the Antioxidant in Food Regulations, I 966 (Great Britain: Parliament, I966c).

Responsibilities for regulations concerning food hygiene are also shared by the 
Ministers of Agriculture, Fisheries and Food and of Health, using the Statutory powers conferred on them by the Food and Drugs Act, 1955 (Section I3). Section 82 of the Act requires that there shall be a Food Hygiene Advisory Council, whose Chairman and members are appointed by the Ministers, and who are representative of the public, the trades and businesses affected by the Act and of workers employed in such trades and businesses. The Act requires that any food hygiene regulations or codes of practice, or any regulations on the labelling and description of food, shall be submitted to the Food Hygiene Advisory Council for consideration in draft form. The Food and Drugs Act also entitles any local authority to make byelaws for 'securing the observance of sanitary and cleanly conditions and practices in connection with the handling, wrapping and delivery of food sold or intended for sale for human consumption ...' (Section 15 ).

Other food control measures affecting the whole population are of a more general nature. An adequate balance of home-produced food is maintained by means of the various Agricultural Support Schemes and the Agricultural Price Review. These schemes endeavour to maintain a balance of agricultural production in the face of variations in the economic climate by attempting to ensure an adequate remuneration to producers of certain foods. These schemes are not a vehicle for food policy, but could be, if required. Two other features of agricultural policy in respect of their effects on the health of the population as a whole deserve mention. Both involve milk and milk products. Firstly, it is an offence under Section 31 of the Food and Drugs Act, 1955, to sell, or use in the manufacture of products destined for human consumption in the UK, milk from any cow which has yielded tuberculous milk. This is the result of many years of effort by the Ministry and the dairying industry to eliminate a major source of tubercular infection. Secondly, as part of official Ministry policy the Brucellosis Eradication Scheme based on vaccination of dairy herds is designed to eliminate from milk the possibility of contamination with Brucella abortus, the cause of contagious abortion in animals and brucellosis or Malta fever in man.

\section{Measures affecting special sections of the population}

The most important of these are concerned with the provision of milk at less than the retail price, irrespective of income, to pregnant women, young children and schoolchildren because of their physiological needs for protein and other constituents of milk. Pregnant women and children up to the age of 5 years are entitled to I pint of liquid milk (or its equivalent as National Dried Milk) a day at about half the retail price, and over $95 \%$ of those entitled to this welfare milk take it (Ministry of Health, private communication). Handicapped children are also entitled to welfare milk. Schoolchildren are entitled to one-third of a pint of milk free on each school day. About $80 \%$ of those entitled to school milk in England and Wales take it (Department of Education and Science, 1966), and nearly 90\% of those in Scotland (Scottish Education Department, I 966).

The Welfare Foods Scheme also provides for certain vitamin products. The authorized allowances were given in regulations made in 1954 (Great Britain: 
Parliament, I954b) and amended in I96I (Great Britain: Parliament, I961). Vitamins $A$ and $D$ tablets are available for expectant and nursing mothers, cod-liver oil for children up to the age of 5 years and welfare orange juice for expectant mothers and children up to the age of 2 years. During recent years the popularity of these products has decreased. Vitamin D is also made available for infants by the fortification of infant foods. National Dried Milk supplied under the Welfare Foods Scheme is required to contain 90 to Ioo i.u. vitamin D per oz. Proprietary brands are similarly fortified, and various proprietary brands of infant cereals are fortified with about 300 i.u. per oz. Special Regulations (Great Britain: Parliament, I960, I966a) apply to preparations made of skimmed milk with added non-milk fat. The composition of those sold as infant foods is controlled.

The history of the provision of meals for schoolchildren and the present nutritional standard of the school dinner have recently been reviewed (Department of Education and Science, I 965 ), and it has been concluded that 'the steady increase in recent years of 3 per cent per annum in the number of children taking school dinners, and the continued physical improvement of children reflected from time to time in the report of school medical officers, suggest that the Service is both basically sound from the nutritional point of view and reasonably popular with children and parents'. The review recommended certain changes in the types of foods served in school dinners, but no material change in nutritional value of about $3 \circ \mathrm{g}$ protein, $30 \mathrm{~g}$ fat and $900 \mathrm{kcal}$. In $196565 \%$ of the children in maintained schools in England and Wales took school dinners (Department of Education and Science, 1966) and $42 \%$ of the children at public and grant-aided schools in Scotland (Scottish Education Department, ig66).

\section{Research and development in foods}

Information on the effects of new methods of producing and treating foods on their nutritive value is scanty, so investigational work has been started. An interdepartmental Committee on Food Composition was instituted in 1964 to coordinate the investigational work done by government departments on food composition, to make recommendations for further work and to disseminate results. The Committee began by co-ordinating the investigations in progress on the effects of modern methods of production and treatment of foods on their nutritional value. 'Three papers have been published: the first (Robertson, Vipond, Tapsfield \& Greaves, I966) on some differences in the composition of broiler and free range chickens, the second (Chamberlain, Collins, Elton, Hollingsworth, Lisle \& Payne, I 966) on the nutrient content of bread made conventionally and by the Chorleywood Bread Process, and the third (Harries, Hubbard, Alder, Kay \& Williams, I968) on the nutritive value of beef from intensively reared animals. Studies on the nutritive value of eggs produced by battery, deep litter and free range systems, on the effects of storage on the nutritional value and flavour of UHT milk and a further study on bread, sampled at the point of sale, are in progress.

This work on possible changes in nutritional values due to changes in food production and processing arises from research and development policies over the whole 
range of our largest group of industries, namely food production, food processing, food storage and distribution. Most of the activity is now naturally industrial but there is a background of work financed and sponsored by the State which influences the general direction of development.

The results of the research pursued in research institutes of the Agricultural Research Council, other institutes and the large company groups specializing in agricultural feeds or machinery are disseminated to food producers through the National Agricultural Advisory Service of the Ministry of Agriculture, Fisheries and Food or by the staffs of the companies themselves. In either case, large-scale trials in experimental farms or husbandry centres precede the final application made by the producer. The development of intensive methods of production not only for beef, poultry meat and eggs but also for crops has considerably increased our home-produced food supplies since the war. An intensive production policy leads to problems of possible changes in nutritive value of foods, quality changes in terms of consumer preferences, damage by machinery and contamination by residues of pesticides with possible, if not controlled, dangers to health. Control of pesticides is by the voluntary Pesticides Safety Precautions Scheme.

Research and development on food as opposed to food production is done by large company groups, the Agricultural Research Council, a Ministry of Technology Research Institute (Torry) and by Research Associations financed by their members and by Government through the Ministry of Technology. There is no government staffed supporting advisory service as in agriculture and so the results of research are made available to food manufacturers and others by publication in scientific or trade journals, by confidential-to-members publications in the Research Associations or for large companies by the direct application of the results of their own research. Government policy is clearly to stimulate industrial research and research in the state-financed research institutes, to encourage its development particularly through the Research Associations and the distribution of information through Research Associations and all other appropriate means.

The official focal point for the discussion of food research problems at the national level is the Food Research Advisory Committee of the Ministry of Agriculture, Fisheries and Food which sits under the Chairmanship of Lord Sainsbury. This has been limited in the past by its terms of reference which permitted consideration of only those problems which by their nature should be financed from public funds. With a widening of the terms of reference of the Committee it should now be possible to bring policy and research and development into closer accord.

Apart from certain food defence problems the Ministry of Agriculture, Fisheries and Food does not engage in food research and development but is directly involved in the projecting and planning of much current work. It was directly responsible for the initial development of Accelerated Freeze Drying (Ministry of Agriculture, Fisheries and Food, 1961) as a technically feasible process for the large-scale treatment of foods.

A developing process which has been exhaustively studied by a Working Party of the Committee on Medical and Nutritional Aspects of Food Policy is the treatment 
of foods with ionising radiations. A full report of the Working Party's study and recommendations has been published (Ministry of Health: Committee on Medical and Nutritional Aspects of Food Policy, 1964). As a result, regulations have been issued (Great Britain: Parliament, 1967), prohibiting the method but arranging for applications to be made for the exemption from the prohibition of specific treatments on individual commodities or groups of commodities. An Advisory Committee has been set up to advise Ministers on these applications.

\section{Conclusion}

Nutrition policy is directed to attempting to ensure that the food of the population is adequate in nutrients, safe, clean and palatable. This requires attention to the needs of the population as a whole but with emphasis on the needs, when known, of the vulnerable groups.

In the longer term the apparently inevitable world shortage of food poses serious problems for the United Kingdom because of its dependence on imports. Research into more intensive methods of production, reduction of wastage in distribution and utilization will therefore be of first importance.

\section{REFERENCES}

Chamberlain, N., Collins, T. H., Elton, G. A. H., Hollingswoth, D. F., Lisle, D. B. \& Payne, P. R. (1966). Br. F. Nutr. 20, 747

Department of Education and Science (1965). The Nutritional Standard of the School Dinner. London: H.M. Stationery Office.

Department of Education and Science (1966). Education in 1965. [Cmnd 2938.] London: H.M. Stationery Office.

Great Britain: Parliament (1954a). Food Standards (Margarine) Order, 1954. Stat, Instrum. no. 613.

Great Britain: Parliament (1954b). Great Britain Order, 1954. Stat. Instrum. no. I401.

Great Britain: Parliament (1955). Food Standards (Butter and Margarine) Regulations, 1955. Stat. Instrum, no. $\mathbf{1} 899$.

Great Britain: Parliament (1960). The Skimmed Milk with Non-Milk Fat Regulations, 196o. Stat. Instrum. no. $233 \mathrm{I}$.

Great Britain: Parliament (196r). Welfare Foods (Great Britain) Amendment Order, 196r. Stat. Instrum. no. 352 .

Great Britain: Parliament (1963). Bread and Flour Regulations, I963. Stat. Instrum. no. 1435.

Great Britain: Parliament (1966a). The Skimmed Milk with Non-Milk Fat (Amendment) Regulations, 1966. Stat. Instrum. no. 850.

Great Britain: Parliament (1966b). Colouring Matters in Food Regulations, 1966. Stat. Instrum. no. 1203.

Great Britain: Parliament (1966c). Antioxidants in Food Regulations, 1966. Stat. Instrum. no. 1500.

Great Britain: Parliament (1967). The Food (Conirol of Irradiation) Regulations, 1967. Stat. Instrum. no. 385 .

Harries, J. H., Hubbard, A. W., Alder, F. E., Kay, M. \& Williams, D. R. (I968). Br. F. Nutr. $22,21$.

Ministry of Agriculture, Fisheries and Food (196r). The Accelerated Freeze Drying (AFD) Method of Food Preservation. London: H.M. Stationery Office.

Ministry of Agriculture, Fisheries and Food: Food Standards Committee (1964). Report on Food Labelling. London: H.M. Stationery Office.

Ministry of Agriculture, Fisheries and Food: Food Standards Committee (1966). Report on Claims and Misleading Descriptions. London: H.M. Stationery Office.

Ministry of Health: Committec on Medical and Nutritional Aspects of Food Policy (1964). Report of the Working Party on Irradiation of Food. London: H.M. Stationery Office.

Robertson, J., Vipond, M. S., Tapsfield, D. \& Greaves, J. P., (I g66). Br. F. Nutr. 20, 675.

Scottish Education Department (1966). Education in Scotland. [Cmnd 2914.] Edinburgh: H.M. Stationery Office. 